\title{
Examining the Factors Affecting Intention to Use of, and User Satisfaction with Online Public Grievance Redressal System (OPGRS) in India
}

\author{
Nripendra P. Rana, Yogesh K. Dwivedi, and Michael D. Williams \\ School of Business, Swansea University, Swansea, SA2 8PP, United Kingdom \\ \{nrananp, ykdwivedi\}@gmail.com, M.D.Williams@swansea.ac.uk
}

\begin{abstract}
The purpose of this paper is to examine the success (by measuring intention to use and user satisfaction) of the online public grievance redressal system (OPGRS) from the perspective of the citizens of India. This is the first time that the success of this e-government system is examined using an IS success model. The model developed includes the constructs such as system quality, information quality, perceived usefulness, user satisfaction, and intention to use. The empirical outcomes provided the positive significant connections between all eight hypothesized relationships between five constructs. The empirical evidence and discussion presented in the study can help the Indian government to improve upon and fully utilize the potential of OPGRS as a useful tool for transparent and corruption free country.
\end{abstract}

Keywords: Online public grievance redressal system, OPGRS, e-government, DeLone and McLean, Seddon, India.

\section{Introduction}

Starting from the early 1990s, the revolution of information and communication and technologies (ICTs) has made major and brisk changes in the day-to-day life of people and governments (Floropoulos et al., 2010). Realizing this, many governments across the world are transforming into new forms of government called electronic government (hereafter, e-government) (Akman et al., 2005) to reinforce and maintain their positions in the global competition (Sharifi and Zarei, 2004). Though egovernment provides obvious benefits to governments, professionals, and organizations, it is citizens who actually predicted to receive a number of benefits (Jaeger, 2003). Looking at this aspect, one of the most significant requirements of citizen's day-to-day life such as their grievances against the government systems, officials, organizations, and bureaucratic structures in a country like India is quite evident. As governments develop e-government systems to deliver services to the people, there is a need for evaluation efforts that could examine their effectiveness (Wang and Liao, 2008) and success. OPGRS is one such e-government system which is primarily meant for addressing the grievances, issues, and problems of citizen's everyday life and gets them resolved online by the high-level government officials 
designated for it. It provides a huge benefit to the people by resolving their problems without much hassle.

Grievance redress mechanism is a part and parcel of the machinery of any administration. No administration can claim to be answerable, responsive, and userfriendly unless it has established a proficient and effectual grievance redress mechanism. In fact, the grievance redress mechanism of a firm is an estimate to examine its efficiency and effectiveness as it provides significant feedback on the working of the administration. The grievances from public are accepted at various points in the Government of India. There are mainly two designated agencies in the central government handling these grievances namely Department of Administrative Reforms and Public Grievances (under Ministry of Personnel, Public Grievances and Pensions) and Directorate of Public Grievances (under Cabinet Secretariat). The public grievance redress mechanism in India functions on a decentralized basis. An officer of the level of Joint Secretary is designated as the Director of Grievances of the Ministry/Department/Organization.

The major reasons of grievances primarily include the socio-economic reasons such as prevalent corruption in the ministries, government organizations, and bureaucratic systems, which are ubiquitous in the current society. The people feel themselves helpless against it and are bound to tolerate it in their day-to-day lives. But, the factors such as lack of awareness and lack of relevant information about whom to complain make this process even more tedious. Looking at this aspect, OPGRS has been designed and developed to take care of such problems of the people without stepping in the offices of ministries and government organizations or even without knowing sometimes where to go to lodge their complaints. In majority of the cases, they don't even know who is accountable to listen to their problems. Therefore, the significance of such e-government systems is felt even more for smooth, transparent and impartial running of the governments. The success of this system can be measured only when a large section of the society adopts this system and the government responds properly to their problems leading to the citizens' satisfaction.

Although, OPGRS offers several advantages (as outlined above), its adoption is currently low. Despite low adoption rate, existing literature has not yet attempted to examine citizens' adoption behaviour and their satisfaction with the use of such an important public administration system. It is evident from the discussion presented above that it would be useful to study intention to adopt or adoption of and satisfaction with this system. Hence, the aim of this study is to undertake an exploratory study to examine the success of OPGRS by exploring citizens' adoptive intention.

The remaining paper is organised as follows to fulfill the desired aim: next section undertake a review of e-government literature based on IS success model, this would be followed by a brief discussion on the utilised theoretical background of DeLone and McLean's (1992, 2003) and Seddon's (1997) IS success models. Section 4 then provides an overview of the proposed research model and justification for the proposed hypotheses followed by a brief discussion on utilised research method. Findings are presented and discussed in Section 6 and 7 subsequently. Finally, conclusion including limitations and future research directions and implications for theory and practice are presented in Section 8. 


\section{Literature Review}

As far as e-government adoption research is concerned, some studies (Chai et al., 2006; Chen, 2010; Floropoulos et al., 2010; Gotoh, 2009; Hsu and Chen, 2007; Hu et al., 2009; Sambasivan et al., 2010; Scott et al., 2009; Teo et al., 2008) have used IS Success Models to analyse the use, intention to use, and satisfaction toward adopting an e-government system. In recent years, many citizens centric Internet based enhanced services implemented by governments of various countries including India. As government develops e-government systems to offer such enhanced services to the citizens, further assessment efforts are required to measure the effectiveness of the egovernment systems. Such evaluation efforts would allow government agencies to determine whether they are capable to deliver what citizens require and provide expected services accordingly (Gupta and Jana, 2003; Wang and Liao, 2008).

From the analysis of the research findings of the various literature studies, Chai et al. (2006) implied that success of e-government depends on how governments offer high quality and user-oriented e-government services to the citizens. One of the major factors of the success of the e-government was government websites. The relationship between the quality of a website and its success has been analysed in some research papers (Chai et al., 2006). Palmer (2002) discussed that quality of a website can be measured by its connection speed, navigability, interactivity, responsiveness, and quality substance. On the other hand, it was found that website quality is supposed to have positively linked toward developing trusting intention on e-commerce website (McKnight et al., 2000). Therefore, website service quality can be considered as one of the strong interpreters of e-government success and user's intention to constantly use an e-government website (Chai et al., 2006).

Hsu and Chen (2007) provided an alternative conceptualization of the IS success model for examining the IS use behaviour of e-government in Taiwanese context. Their analysis indicated that user intention to use IS in e-government is governed by social (i.e. normative pressure) and functional value (i.e. information and system quality) rather than conditional value (i.e. system quality) and satisfaction. Teo et al. (2008) have analysed the influence of trust on the specific e-government systems on the quality constructs (i.e. information, system, and service quality) of the IS success model. They argued that higher level of citizen's trust would be positively associated with information, system, and service quality of the systems (Teo et al., 2008). Similarly, backed by the IS success model, Wang et al. (2010) devised a model for citizen's sustainable trust in e-government.

Gotoh (2009) undertook a similar analysis of the online tax declaration services for the Japanese government and examined it quantitatively to elucidate the factors that enhance user's satisfaction with such services. The paper used IS success models with two amendments where preparation quality and result quality were the constructs used apart from system quality, which was directly driven from the IS success model. Hu et al. (2009) examined the determinants of service quality and continuance intention on the eTax system in context of Hong Kong. The data analysis supported both service traits (i.e. security and convenience) and one technology trait (i.e. perceived ease of use) as the key determinants of the service quality. They also observed that perceived usefulness was not found as the strongest predictor of continuance intention but service quality was. 
Scott et al. (2009) provided a multi-faceted framework for understanding the success of e-government websites from the citizen's perspectives. They established the role of net benefits in the evaluation of e-government success and extended the knowledge of e-government success by determining the influence IT quality constructs. Chen (2010) discussed taxpayer's satisfaction with the online system for filing the individual income tax returns in context of Taiwan. The system under discussion covered its information, system, and service qualities, which are the precursors of the user's satisfaction with any system. By the use of DeLone and McLean's IS success model, the author intended to demonstrate how the use of the system could be enhanced by the increasing software satisfaction with it. The research also found that information and system quality are significant factors toward achieving this goal (Chen, 2010).

Floropoulos et al. (2010) measured the success of the Greek taxation information system (TAXIS) from the perspective of expert employees using the constructs including information, system, and service quality, perceived usefulness, and user satisfaction and found the strong links between five success constructs. However, they found the effect of system quality on perceived usefulness quite low and on user satisfaction as non-significant. Sambasivan et al. (2010) used an extended IS success model of DeLone and McLean (2003) to examine the factors that influence the intention to use and actual use of the electronic procurement system by various ministries in the Malaysian government. They used DeLone and McLean IS success model by extending it with the factors such as trust, facilitating conditions, and webdesign quality and found them strongly linked with intention to use.

\section{Research Model Development and Hypotheses}

\subsection{Theoretical Background - IS Success Models}

There are primarily three theories given in the area of IS success. The first IS success model was given by DeLone and McLean (1992) with six factors namely system quality, information quality, use, user's satisfaction, individual impact, and organizational impact (DeLone and McLean, 1992). In order to address criticism by several studies (such as Seddon and Kiew, 1996) relating to some of its constructs such as individual and organizational impact and use, Seddon (1997) introduced a respecified model of DeLone and McLean where use of the system was considered to have results of various types, perceived usefulness was introduced in the model as an IS measure. Latter in the year 2003, DeLone and McLean discussed many of the significant IS research efforts that have applied, validated, challenged, and offered enrichments to their original model. The updated IS success model (DeLone and McLean, 2003) incorporated a new construct 'service quality' and substituted the variables, individual and organizational impact, with net benefits with accounting for benefits at different levels of analysis. 


\subsection{Overview of Proposed Research Model for Examining Success Factors of OPGRS}

The theoretical development is based on the above described IS success models (DeLone and McLean, 1992; 2003; Seddon, 1997). The decision for not considering certain constructs of these models for proposing research model for this study is based on certain logical facts. For example, service quality is concerned with measuring the quality of service obtained by the IT departments as opposed to the specific IT applications. It mainly examines user's beliefs and their insight of IT department (Petter et al., 2008). Since this study is concerned with a specific application (i.e. OPGRS), it was deemed inappropriate to include service quality in the proposed research model. The construct 'use' was also excluded from the proposed model as respondents of this study were potential adopters ('not actual users') of the systems. Although, they were shown the working of the system and its benefits and are expected to use this system in the future, they had not have yet experience with the system. For the purpose of this study the perceived usefulness construct from the Seddon's (1997) model was added to replace use. Seddon and Kiew (1996) and Seddon (1997) argued that non-use of a system does not necessarily indicate that it is not useful; it may simply indicate that the potential users have other tasks to perform (Seddon, 1997; Seddon and Kiew, 1996). Such logical arguments further justifies basis for the inclusion of perceived usefulness as an appropriate construct in the proposed model.

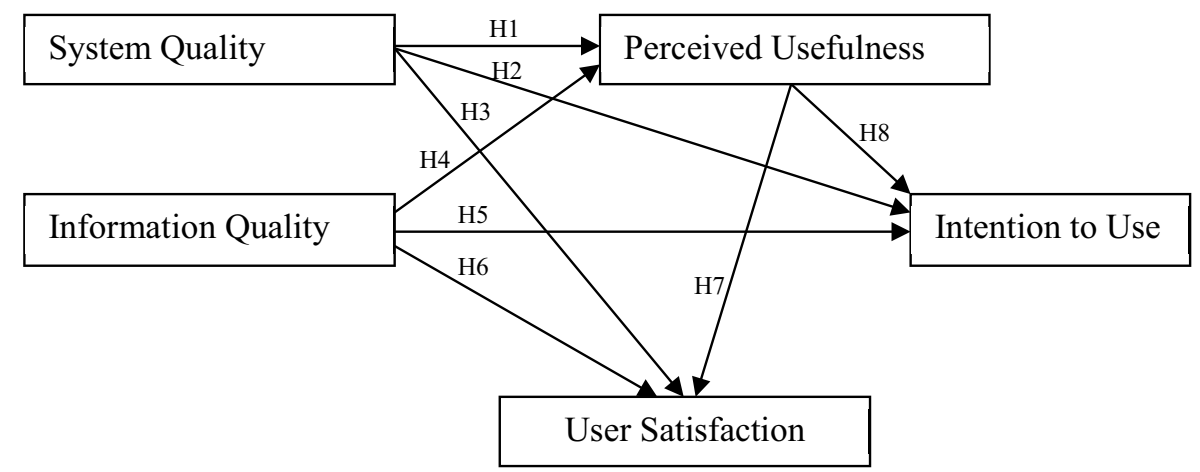

Fig. 1. The proposed research model

Considering above discussion, proposed research model (see Fig. 1) postulate that system quality, information quality will have significant influence on perceived usefulness and these three constructs together will be significantly related to intention to use, and user satisfaction. Testing the postulated relationships (See Table 2 for the list of hypotheses) can help to extrapolate the success of online public grievance redressal systems. 


\subsection{Hypotheses Development}

As illustrated in Fig. 1, a total of eight hypotheses are proposed based on the relationships between five constructs. The core (independent) constructs are listed and defined in Table 1.

Table 1. Definitions of core constructs used in proposed model (Adopted from Seddon, 1997)

\begin{tabular}{|l|l|}
\hline Variable/Construct & Definition \\
\hline System Quality & $\begin{array}{l}\text { System quality is concerned with whether or not there are } \\
\text { 'bugs' in the system, the consistency of the user interface, } \\
\text { ease of use, quality of documentation, and sometimes, } \\
\text { quality and maintainability of the program code. }\end{array}$ \\
\hline Information Quality & $\begin{array}{l}\text { Information quality is concerned with the issues such as the } \\
\text { relevance, timeliness, and accuracy of information } \\
\text { generated by an information system. Not all applications of } \\
\text { IT involve the production of information for decision- } \\
\text { making (e.g., a word processor does not produce any } \\
\text { information) so information quality is not a measure that } \\
\text { can be applied to all systems. }\end{array}$ \\
\hline $\begin{array}{l}\text { Perceived } \\
\text { Usefulness }\end{array}$ & $\begin{array}{l}\text { Perceived usefulness is a perceptual indicator of the degree } \\
\text { to which the stakeholder believes that using a particular } \\
\text { system has enhanced his or her job performance, or his or } \\
\text { her group's or organization's performance. }\end{array}$ \\
\hline
\end{tabular}

Table 2. A list of proposed hypotheses

\begin{tabular}{|l|l|}
\hline H\# & Hypothesis \\
\hline H1 & $\begin{array}{l}\text { System quality has a positive and significant relationship with perceived } \\
\text { usefulness }\end{array}$ \\
\hline H2 & $\begin{array}{l}\text { System quality has a positive and significant relationship with intention to } \\
\text { use }\end{array}$ \\
\hline H3 & $\begin{array}{l}\text { System quality has a positive and significant relationship with user } \\
\text { satisfaction }\end{array}$ \\
\hline H4 & $\begin{array}{l}\text { Information quality has a positive and significant relationship with } \\
\text { perceived usefulness }\end{array}$ \\
\hline H5 & $\begin{array}{l}\text { Information quality has a positive and significant relationship with intention } \\
\text { to use }\end{array}$ \\
\hline H6 & $\begin{array}{l}\text { Information quality has a positive and significant relationship with user } \\
\text { satisfaction }\end{array}$ \\
\hline H7 & $\begin{array}{l}\text { Perceived usefulness has a positive and significant relationship with user } \\
\text { satisfaction }\end{array}$ \\
\hline H8 & $\begin{array}{l}\text { Perceived usefulness has a positive and significant relationship with } \\
\text { intention to use }\end{array}$ \\
\hline
\end{tabular}




\section{System Quality $\rightarrow$ Perceived Usefulness}

Seddon and Kiew (1994) examined a part of DeLone and McLean (1992) IS success model and replaced 'use' with 'usefulness' and their outcomes partially supported DeLone and McLean (1992) IS success model. After replacing use by usefulness, the influence of system quality on perceived usefulness was found very significant. Latter, Fraser and Salter (1995) also obtained a very similar result after replicating Seddon and Kiew's (1994) study. Ease of use has been devised as one of the characteristics of system quality, and the meta-analytic results of this very frequently occurring relationship (in other words, impact of ease of use on usefulness) have been supported and found positive and significant for various categories (King and He, 2006). Examining the success of a Greek taxation information system (TAXIS), Floropoulos et al. (2010) found a strong connection of system quality on perceived usefulness. However, the effect of system quality on perceived usefulness was found to be very low. It was argued that sample considered was largely based on computer and Internet literates and hence might not be a crucial factor for determining perceived usefulness. Therefore, we hypothesize:

H1: System quality has a positive and significant effect on perceived usefulness of the online public grievance redressal systems.

\section{System Quality $\rightarrow$ Intention to Use}

The individual meta-analyses results of DeLone and McLean (2003) IS success model supported and indicated a positive and a highly significant relationship of system analysis on intention to use (Petter and McLean, 2009). The impact of ease of use, which is considered as one of the measures of system quality is already established as positive and significant on intention to use in majority of cases (58 out of 101 relationships found significant as per Lee et al., (2003)) and through the meta-analysis under various categories (King and He, 2006) as well. Therefore, we hypothesize:

$\mathrm{H} 2$ : System quality has a positive and significant effect on intention to use of the online public grievance redressal systems.

\section{System Quality $\rightarrow$ User Satisfaction}

The prior empirical findings (Iavari, 2005; Rai et al., 2002; Seddon, 1997; Seddon and Kiew, 1996; Wang and Liao, 2008) have supported the positive and significant impact of system quality on user satisfaction as discussed in DeLone and McLean's model. That indicates that the higher levels of system quality are positively associated to higher levels of user satisfaction. However, analysing TAXIS in context of Greece, Floropoulos et al. (2010) found it non-significant. The authors argued that the system quality may not be the prominent factor in measuring satisfaction given the nature of sample being sufficiently computer and Internet literate. However, measuring the egovernment system success using the validation of DeLone and McLean model, Wang and Liao (2008) found a significant impact of system quality on user's satisfaction. Therefore, we hypothesize:

H3: System quality has a positive and significant effect on user satisfaction of the online public grievance redressal systems. 


\section{Information Quality $\rightarrow$ Perceived Usefulness}

This relationship has been supported by Seddon (1997) IS success model, where they substituted 'IS use' of DeLone and McLean (1992) success model by perceived usefulness. Seddon (1997) pointed out that perceived usefulness is impacted directly by beliefs about information quality. Latter, Rai et al. (2002) analysed and validated Seddon's (1997) and its amended models and found the effect of information quality on perceived usefulness as positive and significant. Similarly, Franz and Robey (1986), Kraemer et al. (1993) and Seddon and Kiew (1996) have also argued that augmented information quality leads to enhanced usefulness. Moreover, Floropoulos et al. (2010) explored the effect of information quality on perceived usefulness in context of Greek TAXIS systems and confirms the Seddon's (1997) argument. Therefore, we hypothesize:

H4: Information quality has a positive and significant effect on perceived usefulness of the online public grievance redressal systems.

\section{Information Quality $\rightarrow$ Intention to Use}

DeLone and McLean (2003) IS updated model has hypothesized and supported the link of information quality on intention to use. Moreover, the effects of information quality on intention to use is also strongly supported by the meta-analytic outcomes of DeLone and McLean IS success model, which showed the strong relationship strength of these variables even for the least overall sample size obtained to perform the metaanalysis (Petter and McLean, 2009). As far as e-government based studies are concerned, they yet need to validate this relationship. Hence, the following hypothesis can be formulated:

H5: Information quality has a positive and significant effect on intention to use of the online public grievance redressal systems.

\section{Information Quality $\rightarrow$ User Satisfaction}

Several prior studies on IS success have demonstrated support for the argument that higher degree of information quality leads to enhanced user satisfaction (Chae and Kim, 2001; Floropoulos et al., 2010; Iavari, 2005; McGill and Hobbs, 2003; Rai et al., 2002; Seddon, 1997; Seddon and Kiew, 1996; Wang and Liao, 2008; Zhang et al., 2005). Petter and McLean's (2009) meta-analytic assessment of DeLone and McLean model has also strongly supported in effect of information quality on user's satisfaction. In context of e-government adoption research, Wang and Liao (2008) presented and validated a model of e-government system success (based on DeLone and McLean (2003) IS success model) and found the influence of information quality on user satisfaction being significantly supported. Similar, results were obtained for TAXIS systems analysed by Floropoulos et al. (2010), where the findings indicated system quality as an important and stronger determinant of employee's satisfaction. Hence, we hypothesize:

H6: Information quality has a positive and significant effect on user satisfaction of the online public grievance redressal systems. 


\section{Perceived Usefulness $\rightarrow$ User Satisfaction}

Seddon (1997) has validated and supported the positive effect of perceived usefulness on user's satisfaction. Rai et al. (2002) specified and empirically measured Seddon (1997) and its amended IS success model and found the significant correlation between perceived usefulness and user's satisfaction. Moreover, findings of Floropoulos et al. (2010) confirmed that perceived usefulness is a strong determinant of user satisfaction in context of TAXIS systems of Greece. They also argued that this relationship has not been explored much by the researchers in the extant literature (Floropoulos et al., 2010). Moreover, the studies like Franz and Robey (1986) and Seddon and Kiew (1996) have also supported a positive correlation between these constructs. Therefore, we hypothesize:

H7: Perceived usefulness has a positive and significant effect on intention to use the online public grievance redressal systems.

\section{Perceived Usefulness $\rightarrow$ Intention to Use}

Building on the prior IS research, the technology acceptance model (TAM) conceptualized usefulness as one of the significant insights leading to intention to adopt new systems (Lee et al., 2003). Research has shown that perceived usefulness influences intended adoption of IT (Gefen and Straub, 2000). As far as e-government adoption research is concerned, this relationship has been examined through the models such as the TAM and extended TAM (TAM2). Subsequently, out of being examined for a total of 24 times, it was found significant in 21 cases across different studies. The meta-analysis also found the collective effect of perceived usefulness on intention to use as significant. However, as per our knowledge, this relationship has not been explored in context of IS success model in e-government research. Considering the overall performance of this relationship across IS research in general and e-government adoption research in particular, the following hypothesis can be formulated:

H8: Perceived Usefulness has a positive and significant influence on intention to use the online public grievance redressal systems.

\section{$4 \quad$ Research Methodology}

For the purpose of examining e-government system success of OPGRS, the researchers considered survey as an appropriate research method (Cornford and Smithson, 1996; Choudrie and Dwivedi, 2005). There are various ways to capture the data, however, a self-administered questionnaire was found to be a suitable as a primary survey instrument of data collection in this research. This is due to the fact that this tackles the issue of reliability of information by reducing and eliminating the way the questions are asked and presented (Conford and Smithson, 1996). Moreover, collecting data from the majority of respondents within a short and specific period of time was a critical issue of this research (Fowler, 2002). Therefore, only closed and multiple-choice questions were included in the questionnaire. The final questionnaire 
consisted of total 30 questions including 10 questions from respondent's demographic characteristics and 20 questions on the five different constructs of the proposed research model. All these questions were multiple-type, closed-ended and seven-point Likert scale type questions. Likert scales (1-7) with anchors ranging from "strongly disagree" to "strongly agree" (Wang and Liao, 2008) were used for all nondemographic based questions. Appendix A lists all the items for the constructs used in this study.

The sample of the study consists of wide spectrum of respondents from different cities of India including New Delhi, Pune, Mumbai, Bangalore, Patna, Siliguri, and Gangtok. From the literature on IS success models, five factors were identified and a questionnaire for examining intention to use and satisfaction was then created and pilot tested with 34 respondents. While the results of the pilot test were found to be valid and reliable measuring instrument, the researchers agreed that further analysis could reduce the set of factors and that further validation efforts were required (Griffiths et al., 2007). Deriving from the success of the pilot test, a total of 1500 questionnaires distributed to respondents through one-to-one and group interaction. The respondents were briefed and demonstrated about the functioning of the online public grievance redressal system and in some cases they were given maximum two days of time to complete the questionnaire. This was done considering the long list of questions in the questionnaire. However, some of the questionnaires were made to respond on spot. A total of 485 completed survey questionnaires were received back. The further scrutiny of questionnaires revealed that 66 of them were partially completed and so rejected from the subsequent analysis. Hence, we were left with 419 usable responses, which made our basis for the empirical analysis for measuring the IS success of OPGRS. The overall response rate was found to be $32.3 \%$ with $27.9 \%$ valid questionnaires.

\section{$5 \quad$ Research Findings}

\subsection{Respondents' Demographic Profile}

This section analyses demographic data (in Table 3) obtained from the respondents. As per the questionnaire results, the average respondent's age ranges from 20 to 34, with males accounting for $67.8 \%$ of the sample and $32.2 \%$ were female. The majority of the population (i.e., 56.1\%) belongs to student community with a fair representation from public- and private-sector employees (i.e., 29.3\%). As far as the educational qualifications are concerned, $82 \%$ of the total population are having a minimum degree of graduation. The computer and Internet literacy and awareness of the respondents can be judged from their very high computer and Internet experience percentage $(\approx 96 \%)$. This higher frequency is also supported by their computer and Internet access at various places and Internet use frequency, which is very high. Therefore, it is argued that the sample of respondents could be the best-fit potential users and adopters of the systems such as online public grievance redressal system. 
Table 3. Demographic characteristics of respondents

\begin{tabular}{|c|c|c|}
\hline Characteristics & Frequency & $\%$ \\
\hline \multicolumn{3}{|l|}{ Age } \\
\hline 20-24 Years & 228 & 54.4 \\
\hline 25-29 Years & 70 & 16.7 \\
\hline 30-34 Years & 52 & 12.4 \\
\hline 35-39 Years & 27 & 6.4 \\
\hline 40-44 Years & 11 & 2.6 \\
\hline 45-49 Years & 13 & 3.1 \\
\hline 50-54 Years & 7 & 1.7 \\
\hline 55-59 Years & 1 & 0.2 \\
\hline$>=60$ Years & 10 & 2.4 \\
\hline \multicolumn{3}{|l|}{ Gender } \\
\hline Male & 284 & 67.8 \\
\hline Female & 135 & 32.2 \\
\hline \multicolumn{3}{|l|}{ Education } \\
\hline Non-Matriculation & 7 & 1.7 \\
\hline Matriculation & 13 & 3.1 \\
\hline 10+2/Intermediate & 55 & 13.1 \\
\hline Graduate & 161 & 38.4 \\
\hline Post-Graduate & 169 & 40.3 \\
\hline Post-Graduate Research & 14 & 3.3 \\
\hline \multicolumn{3}{|l|}{ Occupation } \\
\hline Student & 235 & 56.1 \\
\hline Unemployed & 18 & 4.3 \\
\hline Pensioner & 7 & 1.7 \\
\hline Employee-Public Sector & 29 & 6.9 \\
\hline Employee-Private Sector & 94 & 22.4 \\
\hline Self-Employed & 36 & 8.6 \\
\hline \multicolumn{3}{|l|}{ Computer Access } \\
\hline Home & 273 & 46.4 \\
\hline Office & 107 & 18.2 \\
\hline Internet Cafe & 83 & 14.1 \\
\hline College/University & 100 & 17.0 \\
\hline Common Service Centre & 12 & 2.0 \\
\hline No Access & 13 & 2.2 \\
\hline \multicolumn{3}{|l|}{ Computer Experience (in Years) } \\
\hline No Experience & 17 & 4.1 \\
\hline 1-3 Years & 99 & 23.6 \\
\hline 4-6 Years & 98 & 23.4 \\
\hline 7-9 Years & 91 & 21.7 \\
\hline$>=10$ Years & 114 & 27.2 \\
\hline
\end{tabular}




\begin{tabular}{|c|c|c|}
\hline Internet Access & & \\
\hline Home & 246 & 42.6 \\
\hline Office & 104 & 18.0 \\
\hline Internet Cafe & 109 & 18.9 \\
\hline College/University & 103 & 17.8 \\
\hline Common Service Centre & 10 & 1.7 \\
\hline No Access & 6 & 1.0 \\
\hline \multicolumn{3}{|l|}{ Internet Experience (in Years) } \\
\hline No Experience & 16 & 3.8 \\
\hline 1-3 Years & 132 & 31.5 \\
\hline 4-6 Years & 122 & 29.1 \\
\hline 7-9 Years & 80 & 19.1 \\
\hline$>=10$ Years & 69 & 16.5 \\
\hline \multicolumn{3}{|l|}{ Internet Use Frequency } \\
\hline Never & 12 & 2.9 \\
\hline Very Rarely & 21 & 5.0 \\
\hline Rarely & 39 & 9.3 \\
\hline Occasionally & 77 & 18.4 \\
\hline Very Frequently & 137 & 32.7 \\
\hline Always & 133 & 31.7 \\
\hline
\end{tabular}

\subsection{Reliability Analysis - Cronbach's Alpha ( $\alpha$ )}

Reliability analysis was performed using Cronbach's alpha. It was used for determining the reliability of the scale, which provides an indication about the internal consistency of the items measuring the same construct (Hair et al., 1992; Zikmund, 1994). Cronbach's alpha reliability for all the constructs except system quality is in the range 0.796-0.881, which is quite good. A Chronbach $(\alpha)$ of greater than 0.7 is considered to be good (Nunnaly, 1978; Hair et al., 1992). Therefore, alphas imply strong reliability for all constructs, but system quality which is at satisfactory level.

Table 4. Cronbach's alpha $(\alpha)$ of constructs

\begin{tabular}{|l|l|}
\hline Construct & Cronbach's Alpha $(\alpha)$ \\
\hline System Quality & 0.548 \\
\hline Information Quality & 0.810 \\
\hline Perceived Usefulness & 0.800 \\
\hline Intention to Use & 0.796 \\
\hline User Satisfaction & 0.881 \\
\hline
\end{tabular}

\subsection{Descriptive Statistics}

Table 5 presents the mean and standard deviation (S.D.) for all the five constructs and their individual items. The high overall as well as individual items' means for most of 
the constructs, except user satisfaction, indicate that respondents react favourably to the IS success measures examined.

Table 5. Descriptive statistics of the constructs and their items

\begin{tabular}{|c|c|c|c|}
\hline Measure & Item & Mean & S.D. \\
\hline System Quality (SQ) & & 5.19 & 0.97 \\
\hline & SQ1 & 5.17 & 1.31 \\
\hline & SQ2 & 5.33 & 1.35 \\
\hline & SQ3 & 5.06 & 1.37 \\
\hline Information Quality (IQ) & & 5.02 & 1.08 \\
\hline & IQ1 & 5.11 & 1.28 \\
\hline & IQ2 & 4.92 & 1.38 \\
\hline & IQ3 & 5.05 & 1.40 \\
\hline & IQ4 & 4.98 & 1.35 \\
\hline Perceived Usefulness (PU) & & 5.29 & 0.96 \\
\hline & PU1 & 5.51 & 1.35 \\
\hline & PU2 & 5.06 & 1.41 \\
\hline & PU3 & 4.97 & 1.51 \\
\hline & PU4 & 5.05 & 1.36 \\
\hline & PU5 & 5.58 & 1.23 \\
\hline & PU6 & 5.55 & 1.23 \\
\hline & & 5.26 & 1.23 \\
\hline Intention to Use (IU) & IU1 & 5.31 & 1.50 \\
\hline & IU2 & 5.20 & 1.46 \\
\hline & IU3 & 5.27 & 1.40 \\
\hline & & 4.15 & 0.95 \\
\hline User Satisfaction (US) & US1 & 5.08 & 1.45 \\
\hline & US2 & 5.12 & 1.45 \\
\hline & US3 & 5.21 & 1.33 \\
\hline & US4 & 5.35 & 1.30 \\
\hline & & & \\
\hline
\end{tabular}

\subsection{Hypotheses Testing}

Table 6, 7, and 8 present output of linear regression model analysed using SPSS 19.0. The analysis presented in Table 6 supported all the hypotheses (i.e. H2, H5, and H8) on intention to use as positive and significant. The constructs SQ, PU, and IQ explain $25.1 \%$ (adjusted $\mathrm{R}^{2}$ ) of the variance in respondents' intention to use the online public grievance redressal system. Since, the overall model is significant $(\mathrm{F}=47.811$, $\mathrm{p}=0.000$ ), the significance of the independent variable was further examined. All independent variables were found significant with $1 \%$ significance level except IQ, which was found significant with $5 \%$ significance level. Therefore, all the three hypotheses $\mathrm{H} 2, \mathrm{H} 5$, and $\mathrm{H} 8$ are supported. 
Table 6. Effect of system quality, perceived usefulness, and information quality on intention to use

\begin{tabular}{|c|c|c|c|c|c|c|}
\hline \multirow[t]{2}{*}{ Model } & \multicolumn{2}{|c|}{$\begin{array}{c}\text { Unstandardized } \\
\text { Coefficients } \\
\end{array}$} & \multirow{2}{*}{\begin{tabular}{|c|}
$\begin{array}{c}\text { Standardized } \\
\text { Coefficients }\end{array}$ \\
Beta \\
\end{tabular}} & \multirow[t]{2}{*}{$\mathrm{t}$} & \multirow[t]{2}{*}{ Sig. } & \multirow[t]{2}{*}{ Result } \\
\hline & $\mathrm{B}$ & S.E. & & & & \\
\hline \multirow{4}{*}{$\begin{array}{c}\text { (Constant) } \\
\text { SQ } \\
\text { PU } \\
\text { IQ }\end{array}$} & 1.409 & 0.326 & & 4.319 & 0.000 & \\
\hline & 0.245 & 0.071 & $0.194 * *$ & 3.469 & 0.001 & Supported \\
\hline & 0.369 & 0.072 & $0.288^{* * *}$ & 5.147 & 0.000 & Supported \\
\hline & 0.126 & 0.060 & $0.111^{*}$ & 2.098 & 0.036 & Supported \\
\hline Model R ${ }^{2}$ & \multicolumn{6}{|l|}{0.257} \\
\hline Adjusted $\mathrm{R}^{2}$ & \multicolumn{6}{|l|}{0.251} \\
\hline $\mathrm{F}$ & \multicolumn{6}{|l|}{47.811} \\
\hline Significance & \multicolumn{6}{|l|}{0.000} \\
\hline
\end{tabular}

[Note: *: $\mathrm{p}<0.05, * *: \mathrm{p}<0.01 ; * * *: \mathrm{p}<0.001$ ][Legend: S.E. = Standard Error, Sig. = Significance]

Table 7 presents the $\beta$-value of independent variables such as SQ, PU, and IQ on US. The analysis exhibits a stronger effect of SQ $(\beta=0.310)$ and IQ $(\beta=0.355)$ on US than IU. However, PU seems to have better influencing BI $(\beta=0.288)$ than US $(\beta=0.109)$. That means, higher the usefulness, higher the intention to use the system rather than being more satisfied. Higher the system and information quality, respondents tend to be more satisfied with the system. That means, OPGRS enhances the overall satisfaction of the respondents by providing accurate, reliable, updated information to name a few in the bureaucratic government system in a country like India.

Table 7. Effect of system quality, perceived usefulness, and information quality on user satisfaction

\begin{tabular}{|c|c|c|c|c|c|c|}
\hline \multirow[t]{2}{*}{ Model } & \multicolumn{2}{|c|}{$\begin{array}{l}\text { Unstandardized } \\
\text { Coefficients }\end{array}$} & $\begin{array}{c}\text { Standardized } \\
\text { Coefficients }\end{array}$ & \multirow[t]{2}{*}{$\mathrm{t}$} & \multirow[t]{2}{*}{ Sig. } & \multirow[t]{2}{*}{ Result } \\
\hline & $\mathrm{B}$ & S.E. & Beta & & & \\
\hline \multirow{4}{*}{$\begin{array}{c}\text { (Constant) } \\
\text { SQ } \\
\text { PU } \\
\text { IQ }\end{array}$} & 0.437 & 0.221 & & 1.982 & 0.048 & \\
\hline & 0.303 & 0.048 & $0.310 * * *$ & 6.343 & 0.000 & Supported \\
\hline & 0.109 & 0.049 & $0.109^{*}$ & 2.246 & 0.025 & Supported \\
\hline & 0.312 & 0.040 & $0.355 * * *$ & 7.723 & 0.000 & Supported \\
\hline Model R ${ }^{2}$ & \multicolumn{6}{|l|}{0.434} \\
\hline Adjusted $\mathrm{R}^{2}$ & \multicolumn{6}{|l|}{0.430} \\
\hline $\mathrm{F}$ & \multicolumn{6}{|c|}{106.098} \\
\hline Significance & \multicolumn{6}{|l|}{0.000} \\
\hline
\end{tabular}

[Note: *: $\mathrm{p}<0.05, * *: \mathrm{p}<0.01 ; * * *: \mathrm{p}<0.001]$ [Legend: S.E. = Standard Error, Sig. = Significance]

All the three hypotheses H3, H6, and H7 have been found positive and significant on user satisfaction. The same set of independent constructs (i.e. SQ, PU, and IQ) 
explains $43 \%$ (adjusted $\mathrm{R}^{2}$ ) of the variance in the respondents' user satisfaction on the system. The overall model was found significant $(\mathrm{F}=106.098, \mathrm{p}=0.000)$, and the significance of the individual independent variables was further verified. It was found that both SQ and IQ were found significant on US with 0.001 significant level whereas PU at 0.05 significant level.

Table 8 summarizes the results of the hypotheses testing the dependent variable perceived usefulness. This model explains $42.6 \%$ of variance of the system OPGRS on respondent's perceived usefulness. Again, the overall model was found significant $(\mathrm{F}=154.538, \mathrm{p}=0.000)$ with the individual independent variables IQ and SQ are significant determinants of respondent's perceived usefulness with a significance level of 0.001. More precisely, the hypotheses H1 and H4 are supported. This time, SQ exhibits stronger effect $(\beta=0.447)$ on perceived usefulness than IQ $(\beta=0.293)$. That indicates, higher the system quality higher will be its usefulness as perceived by its users.

Table 8. Effect of information quality and system quality on intention to use

\begin{tabular}{|c|c|c|c|c|c|c|}
\hline \multirow{2}{*}{ Model } & \multicolumn{2}{|c|}{$\begin{array}{l}\text { Unstandardized } \\
\text { Coefficients }\end{array}$} & $\begin{array}{l}\text { Standardized } \\
\text { Coefficients }\end{array}$ & \multirow[t]{2}{*}{$\mathrm{t}$} & \multirow{2}{*}{ Sig. } & \multirow{2}{*}{ Result } \\
\hline & $\mathrm{B}$ & Std. Error & Beta & & & \\
\hline \multirow{3}{*}{$\begin{array}{c}\text { (Constant) } \\
\text { IQ } \\
\text { SQ }\end{array}$} & 1.706 & 0.207 & & 8.249 & 0.000 & \\
\hline & 0.259 & 0.039 & $0.293 * * *$ & 6.672 & 0.000 & Supported \\
\hline & 0.440 & 0.043 & $0.447 * * *$ & 10.178 & 0.000 & Supported \\
\hline Model R $^{2}$ & \multicolumn{6}{|l|}{0.426} \\
\hline Adjusted $\mathrm{R}^{2}$ & \multicolumn{6}{|l|}{0.424} \\
\hline $\mathrm{F}$ & \multicolumn{6}{|l|}{154.538} \\
\hline Significance & \multicolumn{6}{|l|}{0.000} \\
\hline
\end{tabular}

[Note: *: $\mathrm{p}<0.05, * *: \mathrm{p}<0.01 ; * * * \mathrm{p}<0.001]$

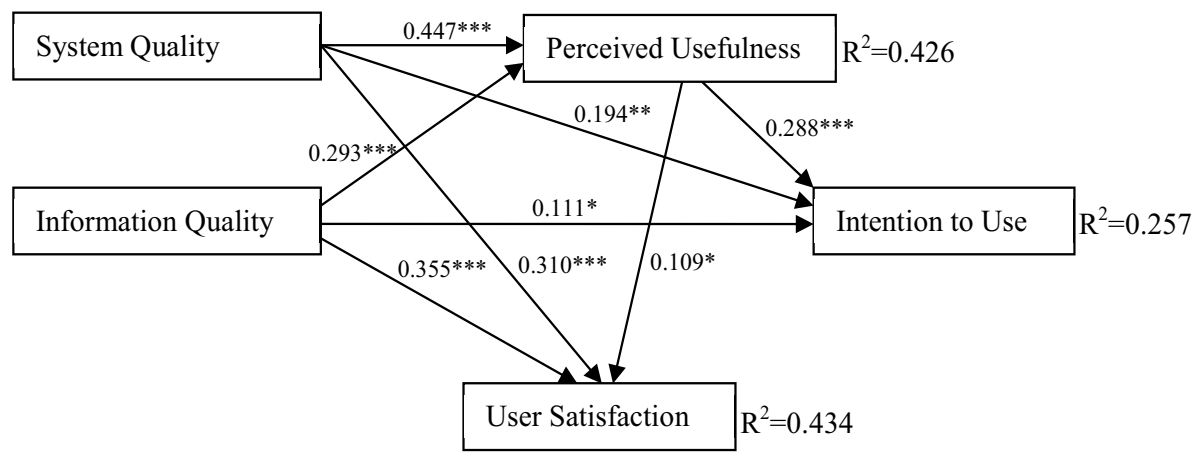

Fig. 2. Validated research model to measure intention to use and user 
The hypothesis testing results of linear regression analysis with the coefficient values (i.e. $\beta$-value), $\mathrm{p}$-value, and $\mathrm{R}^{2}$-value are presented along the research model in Fig. 2.

\section{Discussion}

The hypothesis testing results indicated that there are strong links between the five constructs supporting the hypotheses. The regression coefficient outcomes indicated that system and information quality are significant positive determinants of perceived usefulness. Moreover, their effect on user satisfaction was even stronger. However, unlike the system and information quality, the effect of perceived usefulness on user satisfaction was significant but its influence on intention to use exhibited even stronger affect as far as OPGRS is concerned. Finally, the findings also revealed that system and information quality are the stronger predictors of perceived usefulness

It is evident from the above analysis that perceived usefulness of the system leads the respondents more toward their intention to use it rather being satisfied. This is due to the fact that although perceived usefulness is found as an effective determinant to measure both intention to use as well as user satisfaction, it is more significant toward intention to use than satisfaction. This may be due to the fact that users would tend to use the system more than being satisfied to the level based on the usefulness of the system. The argument of intention to use a system based on its perceived usefulness has already been well established by Davis (1989) through TAM model and supported by a number of studies using this model. Moreover, a significant impact of perceived usefulness on user's satisfaction (established by Seddon, 1997) has also been supported by Colesca and Dobrica (2008) in their study of e-government adoption in Romanian context.

As OPGRS is relatively a new system and not being used by the sample population for lodging their complaints and grievances, the stronger significant relationship between perceived usefulness and satisfaction can be expected only when the system is used to a certain extent. On the other hand, the predictors such as system and information quality make the respondents more satisfied than intending to use the system though all the relationships were found significant. This may be due to the fact that the respondents believed about how the system is going to benefit them without much hassle. The other significant reason for the respondents being more satisfied to this system is it does not involve any transactions and would take away their fear to lose anything monetarily. However, all these relationships were found significant as described in DeLone and McLean IS success Model (2003). Finally, the constructs system and information quality strongly determines the perceived usefulness of the system. This is due to the simple reason that this is the flexibility, conciseness, ease of use, faster response time, user-friendly interface, accuracy, completeness, and significance of the system which can make it more useful for its use. This strong empirical evidence also supports Seddon (1997) view of IS success model. 


\section{Conclusion}

This research is a response to a call for the continuous challenge and validation of IS success models in different contexts (DeLone and McLean, 2003, Rai et al., 2002). The purpose of this study is to examine the success of OPGRS through an egovernment based IS success model, which is developed using DeLone and McLean's and Seddon's IS success models. Therefore, we integrated the constructs of these two models to form a model that could explain the success of OPGRS as perceived by the sample of respondents in context of India. All the eight hypotheses performed significantly as per the expectations of the IS success models. Therefore, it is quite evident from the empirical findings that the implementation of OPGRS seems to be quite successful even though it is not a very old system. However, it was sensed that the government should take more initiatives to enhance the information quality of the system to attract more positive responses from the citizens toward their inclination to use the system. Moreover, there should be an emphasis to highlight the usefulness of the system as a whole to make the citizens aware, prompted, and satisfied.

\subsection{Limitations and Future Research Directions}

Even though the thorough process has allowed us to develop and validate the egovernment based system success model, this study has a number of limitations that can be taken care of in the future research. Firstly, the exploration of IS system success model in context of e-government system is relatively new to the egovernment researchers. Therefore, the caution needs to be taken while generalizing its findings to the other categories of users (i.e. in G2B and G2G contexts) as well as applying this model in other developing country even in G2C context. Secondly, this model does not measure the concerns of net benefits as defined in the IS success model (DeLone and McLean, 2003; Seddon, 1997). Hence, measuring net benefits from the citizen's points of view can reveal some more facts about the system. However, future researchers need clearly and carefully define the stakeholders and situations under which the net benefits are to be examined (DeLone and McLean, 2003). Thirdly, the study has not validated this system for specific cultural and geographical contexts. Future research can dig out more on these aspects. Finally, this study has performed empirical investigation of e-government systems success based on the snapshot view of the sample. The longitudinal view of sample data would allow the researchers to better explore the facts about the actual use of the system and it's after effect.

\subsection{Implications for Theory and Practice}

The first theoretical implication of this research is that this system is tested for the first time for its success measure. Secondly, we have integrated DeLone and McLean's (2003) and Seddon's (1997) IS success models to provide a better understanding of OPGRS's success. The model presented here can be tested further based on longitudinal nature of data gathered from the same set of sample after they 
use the system for some time or data collected from those respondents who are already using the system. The empirical testing outcomes of the hypotheses linked to the model can help researchers toward a better understanding of citizen's intention to use and satisfaction with the system. The results will allow the e-government practitioners to realize about the factors to give more attention for increasing the citizen's satisfaction and intention to use the system. The current link of information quality with intention to use the system is although significant, it is not strong. The system designer should pay more attention toward enhancing the standard of information quality of the system to strengthen people's intention to use it. The practitioners should be asked to reinforce perceived usefulness of the system in such a way that they can ensure user's satisfaction to a larger extent.

\section{References}

Adams, D.A., Nelson, R.R., Todd, P.A.: Perceived usefulness, ease of use, and usage of information technology: A replication. MIS Quarterly 16(2), 227-247 (1992)

Akman, I., Yazici, A., Mishra, A., Arifoglu, A.: E-Government: A global view and an empirical evaluation of some attributes of citizens. Government Information Quarterly 22, 239-257 (2005)

Chae, M., Kim, J.: Information quality for mobile internet services: A theoretical model with empirical validation. In: Proceedings of the Twenty-second International Conference on Information Systems New Orleans, LA, USA, pp. 43$54(2001)$

Chai, S., Herath, T.C., Park, I., Rao, H.R.: Repeated Use of E-Gov Web Sites: A Satisfaction and Confidentiality Perspective. International Journal of Electronic Government Research 2(3), 1-22 (2006)

Chen, C.-W.: Impact of quality antecedents on taxpayer satisfaction with online taxfiling systems - An empirical study. Information \& Management 47, 308-315 (2010)

Choudrie, J., Dwivedi, Y.K.: Investigating the research approaches for examining technology adoption issues. Journal of Research Practice 1(1), Article D1 (2005)

Colesca, S.E., Dobrica, L.: Adoption and use of e-government services: The case of Romania. Journal of Applied Research and Technology 6(3), 204-217 (2008)

Cornford, T., Smithson, S.: Project Research in Information Systems: A Student's Guide. Macmillan Press Ltd., London (1996)

Davis, F.D.: Perceived usefulness, perceived ease of use, and user acceptance of information technology. MIS Quarterly 13(3), 318-346 (1989)

DeLone, W.H., McLean, E.R.: Information systems success: The quest for the dependent variable. Information Systems Research 3(1), 60-95 (1992)

Delone, W.H., McLean, E.R.: The DeLone and McLean model of information systems success: A ten-year update. Journal of Management Information Systems 19(4), 9-30 (2003)

Floropoulos, J., Spathis, C., Halvatzis, D., Tsipouridou, M.: Measuring the success of the Greek Taxation Information System. International Journal of Information Management 30, 47-56 (2010)

Fowler, F.J.: Survey Research Methods. SAGE Publications Inc., London (2002) 
Franz, C.R., Robey, D.: Organisational context, user involvement and the usefulness of information systems. Decision Sciences 17, 329-356 (1986)

Gefen, D., Straub, D.: The Relative Importance of Perceived Ease of Use in IS Adoption: A Study of E-Commerce Adoption. Journal of the Association for Information Systems 1(8), 1-28 (2000)

Gotoh, R.: Critical factors increasing user satisfaction with e-government services. Electronic Government, an International Journal 6(3), 252-264 (2009)

Griffiths, J.R., Jhonson, F., Hartley, R.J.: User satisfaction as a measure of system performance. Journal of Librarianship and Information Science 39(3), 142-152 (2007)

Gupta, M.P., Jana, D.: EGovernment evaluation: A framework and case study. Government Information Quarterly 20(4), 365-387 (2003)

Hair, J.F., Anderson, R.E., Tatham, R.L., Black, W.C.: Multivariate data analysis, with readings, 3rd edn. Macmillan Publishing Company, New York (1992)

Hsu, F.-M., Chen, T.-Y.: Understanding Information Systems Usage Behavior in EGovernment: The Role of Context and Perceived Value. In: Pacific Asia Conference on Information Systems, pp. 477-490 (2007)

Hu, P.J.-H., Brown, S.A., Thong, J.Y.L., Chan, F.K.Y., Tam, K.Y.: Determinants of Service Quality and Continuance Intention of Online Services: The Case of eTax. Journal of the American Society for Information Science and Technology 60(2), 292-306 (2009)

Iavari, J.: An empirical test of the DeLone-McLean model of information system success. The Data Base for Advances in Information Systems 36(2), 8-27 (2005)

Jaeger, P.T.: The endless wire: E-Government as global phenomenon. Government Information Quarterly 20(4), 323-331 (2003)

King, W.R., He, J.: A meta-analysis of the technology acceptance model. Information \& Management 43(6), 740-755 (2006)

Kraemer, K.L., Danzinger, J.N., Dunkle, D.E., King, J.L.: The usefulness of computer-based information to public managers. MIS Quarterly 17(2), 129-148 (1993)

Lee, Y., Kozar, K.A., Larsen, K.R.T.: The Technology Acceptance Model: Past, Present, and Future. Communications of the Association for Information System 12, 752-780 (2003)

McGill, T., Hobbs, V.: User-developed applications and information systems success: A test of DeLone and McLean's model. Information Resources Management Journal 16, 24-45 (2003)

McKnight, D.H., Choudhury, V., Kacmar, C.: Trust in e-commerce vendors: A twostage model. In: Proceedings of the 21st International Conference on Information Systems, Brisbane, Queensland, Australia (2000)

Nunnaly, J.: Psychometric theory. McGraw-Hill, New York (1978)

Palmer, J.W.: Web site usability, design, and performance metrics. Information Systems Research 13(2), 151-167 (2002)

Petter, S., McLean, E.R.: A meta-analytic assessment of the DeLone and McLean IS success model: An examination of IS success at the individual level. Information \& Management 46(3), 159-166 (2009)

Petter, S., DeLone, W., McLean, E.: Measuring information systems success: models, dimensions, measures, and interrelationships. European Journal of Information Systems 17, 236-263 (2008) 
Rai, A., Lang, S.S., Welker, R.B.: Assessing the validity of IS success models: An empirical test and theoretical analysis. Information Systems Research 13(1), 50-69 (2002)

Sambasivan, M., Wemyss, G.P., Rose, R.C.: User acceptance of a G2B system: A case of electronic procurement system in Malaysia. Internet Research 20(2), 169187 (2010)

Scott, M., DeLone, W.H.: Understanding Net Benefits: A Citizen-Based Perspective on E-government Success. In: International Conference on Information Systems, pp. 1-11 (2009)

Seddon, P.B.: A respecification and extension of the DeLone and McLean model of IS success. Information Systems Research 8(3), 240-253 (1997)

Seddon, P.B., Kiew, M.-Y.: A partial test and development of the DeLone and McLean model of IS success. In: DeGross, J.I., Huff, S.L., Munro, M.C. (eds.) Proceedings of the International Conference on Information Systems, pp. 99-110. Association for Information Systems, Atlanta (1994)

Seddon, P.B., Kiew, M.Y.: A partial test and development of DeLone and McLean's model of IS success. Australian Journal of Information Systems 4(1), 90-109 (1996)

Sharifi, H., Zarei, B.: An adaptive approach for implementing e-government in I.R. Iran. Journal of Government Information 30, 600-619 (2004)

Teo, T.S.H., Srivastava, S.C., Jiang, L.: Trust and Electronic Government Success: An Empirical Study. Journal of Management Information Systems 9(3), 99-131 (2008)

Wang, T., Cao, Y., Yang, S.: Building the Model of Sustainable Trust in Egovernment. In: 2nd IEEE International Conference on Information and Financial Engineering, pp. 698-701 (2010)

Wang, Y.-S., Liao, Y.-W.: Assessing eGovernment systems success: A validation of the DeLone and McLean model of information systems success. Government Information Quarterly 25, 717-733 (2008)

Zhang, Z., Leeb, M.K.O., Huanga, P., Zhang, L., Huang, X.: A framework of ERP systems implementation success in China: An empirical study. International Journal of Production Economics 98, 56-80 (2005)

Zikmund, G.W.: Business research methods, 4th edn. The Dryden Press, New York (1994)

\section{Appendix A. Survey items used in this study}

\section{Information Quality}

IQ1 The public grievance redressal system would provide sufficient information

IQ2 Through public grievance redressal system, I would get the information I need in time

IQ3 Information provided by public grievance redressal system would be up-to-date

IQ4 Information provided by public grievance redressal system would be reliable

\section{System Quality}

SQ1 The public grievance redressal system would be user friendly 
SQ2 I would find the public grievance redressal system easy to use

SQ3 I would find it easy to get the public grievance redressal system to do what I would like it to do

\section{Perceived Usefulness}

PU1 Using the public grievance redressal system would enable me to accomplish lodging complaint more quickly

PU2 Using the public grievance redressal system would improve my overall performance

PU3 Using the public grievance redressal system would increase my productivity

PU4 Using the public grievance redressal system would enhance my effectiveness

PU5 Using the public grievance redressal system would make it easier to lodge my complaint

PU6 I would find the public grievance redressal system useful in lodging and monitoring complaint

\section{User Satisfaction}

US1 I feel that public grievance redressal system would adequately meet my needs of interacting with government agency

US2 Public grievance redressal system would efficiently fulfill my needs of interacting with government agency

US3 Overall, I would be satisfied with the public grievance redressal system

\section{Intention to Use}

IU1 I intend to use the public grievance redressal system

IU2 I predict that I would use the public grievance redressal system

IU3 I plan to use the public grievance redressal system in the near future 